\title{
MR and CT Findings of Temporal Bone Langerhans Cell Histiocytosis ${ }^{1}$
}

\author{
Jae Ig Bae, M.D., Hee Jung Lee, M.D., Heung Sik Kim, M.D. ${ }^{2}$
}

Purpose: To describe the MRI and CT findings of temporal bone Langerhans cell histiocytosis.

Materials and Methods: The MRI $(n=8)$ and CT $(n=7)$ findings of nine lesions of temporal bone Langerhans cell histiocytosis in six children were retrospectively reviewed. Eight lesions were pathologically confirmed and one was clinically diagnosed. The findings were analyzed for bilaterality, location, lesion extent, signal intensity, the attenuation of soft tissue lesions seen at MRI or precontrast CT, enhancement pattern at MRI or $\mathrm{CT}$, and the pattern of bony destruction at CT.

Results: Bilateral involvement was present in three of six patients (50\%). Lesions were most frequently located in the mastoid $(n=8,89 \%)$, followed by the petrous ridge $(\mathrm{n}=6,67 \%)$, and the squamous portion $(\mathrm{n}=3,33 \%)$. Seven $(78 \%)$ lesions extended to the ipsilateral cavernous sinus $(n=3)$, sphenoid bone $(n=3)$, orbit $(n=2)$, or epidural space $(n=2)$. The signals of the soft tissue lesions were isointense in five cases $(63 \%)$ on T1-weighted images and hyperintense in six $(75 \%)$ on T2-weighted images. Five lesions $(71 \%)$ were isodense on precontrast CT scans. The enhancement patterns were inhomogeneous in six cases $(75 \%)$ at MRI, and homogeneous in five $(71 \%)$ at CT. All lesions demonstrated bony destruction without periosteal reaction and five $(71 \%)$ showed ill-defined destruction, with crossing sutures.

Conclusion: Familiarity with findings of predominant mastoid involvement, isointense or isodense soft tissue lesions seen on T1-weighted images or at precontrast CT, with relatively homogeneous enhancement at $\mathrm{CT}$, and irregular bony destruction with crossing sutures may be helpful in narrowing the diagnosis of temporal bone Langerhans cell histiocytosis.

\section{Index words : Histiocytosis}

Neoplasms, in infants and children

Temporal bone, CT

\footnotetext{
${ }^{1}$ Department of Diagnostic Radiology, Keimyung University School of Medicine, Dongsan Medical Center, 194, Dongsandong, Taegu, Korea. ${ }^{2}$ Department of Pediatrics, Keimyung University School of Medicine, Dongsan Medical Center, 194, Dongsandong, Taegu, Korea.

Received March 29, 2001; Accepted August 30, 2001

Address reprint requests to : Hee Jung Lee, M.D., Department of Diagnostic Radiology, Keimyung University School of Medicine, Dongsan Medical Center, 194, Dongsandong, Taegu 700-310, Korea.

Tel. 82-53-250-7766, 7198 Fax. 82-53-250-7766

E-mail: hjlee@dsmc.or.kr
} 
Langerhans cell histiocytosis (LCH) refers to a group of disorders in which the idiopathic proliferation of histiocytes produces either focal or systemic manifestation (1). The disease may affect people of any age but usually occurs between the ages of 1 and 5 years. Temporal bone involvement of LCH is uncommon, with a reported frequency of between $18 \%$ and $61 \%$ (2). Clinical misdiagnosis is common because the otologic findings can mimic those of acute and chronic infectious ear disease. In addition, the imaging findings may be confused with those of mastoiditis, cholesteatoma, and malignancies such as rhabdomyosarcoma or other metastatic tumors (3). Recognition of the radiologic findings is therefore important in the differentiation of disease from inflammatory and tumorous conditions. The Imaging findings of temporal bone LCH have been sporadically described in a limited number of cases (3-5). The purpose of this study was to determine the MR and CT findings of temporal bone $\mathrm{LCH}$, and thus narrow the differential diagnosis in the pediatric age group.

\section{Materials and Methods}

We retrospectively investigated the $\mathrm{MR}$ and $\mathrm{CT}$ findings of nine temporal bone $\mathrm{LCH}$ lesions which ocurred in six children over a five-year period. There were five boys and one girl, and they were aged between 6 months and 12 years (mean, 6.1 years). Eight lesions were pathologically confirmed by excision $(n=5)$ or needle aspiration biopsy $(n=3)$. and the other lesion was diagnosed clinically using the same imaging and clinical parameters as those used for the contralateral lesion confirmed by needle aspiration biopsy.

MR examinations were performed in five patients
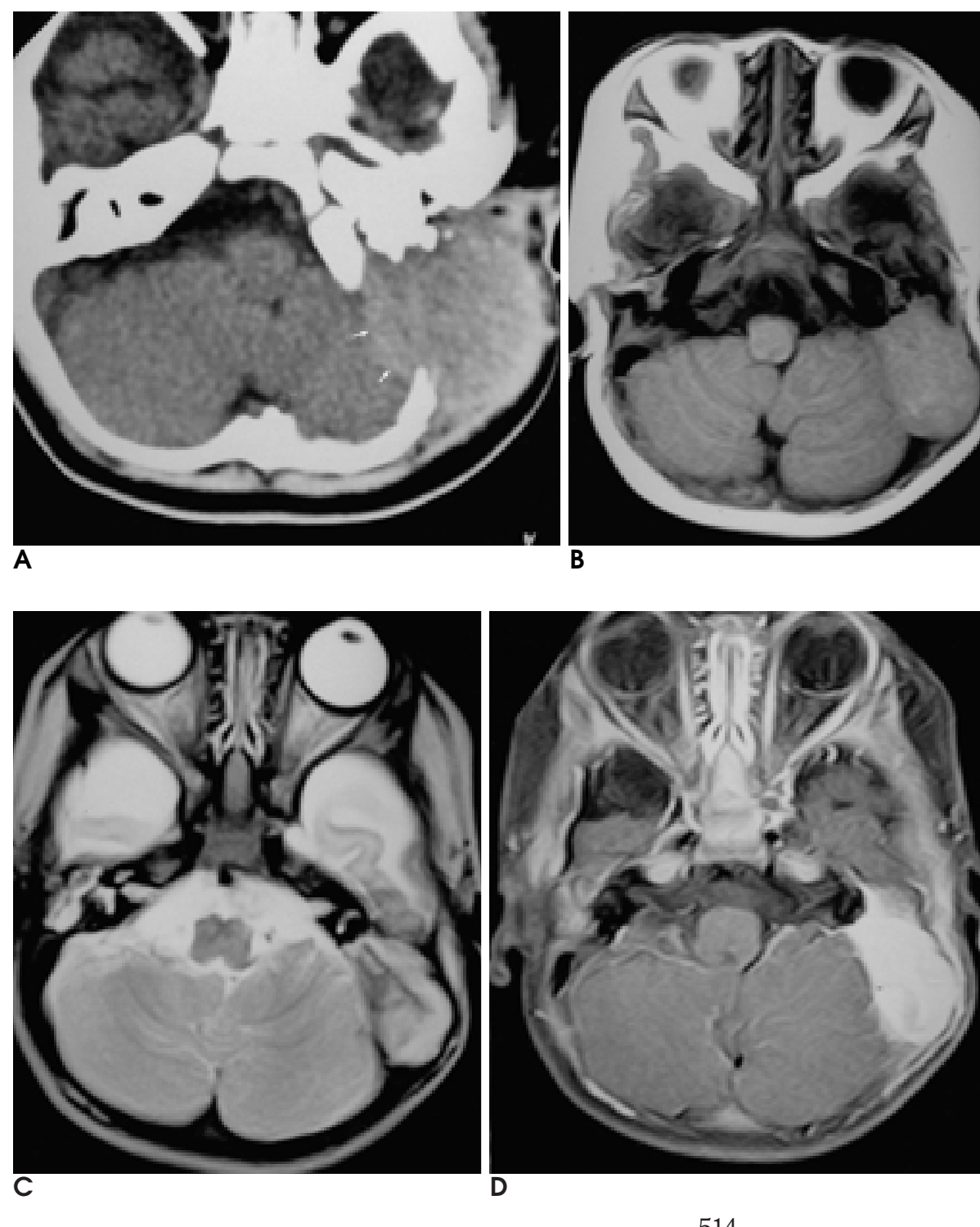

Fig. 1. Lesion 5. An 11-year-old boy presented with a left postauricular lump.

Precontrast CT (A) demonstrates a large isodense soft tissue mass involving the left mastoid, the petrous ridge of the temporal bone, and the occipital bone with epidural extension (arrows). Signal intensities of the lesion were isointense on T1-weighted image (B) and iso-to hyperintense on T2-weighted image (C). Gd-enhanced MR image (D) demonstrates homogeneous enhancement of the lesion. 
(eight lesions), using a 1.5T Magnetom Vision system (Siemens, Erlangen, Germany) and the following imaging sequences: axial T1- and T2-weighted; contrast-enhanced axial and coronal T1-weighted. The imaging parameters were 4000/19 (repetition time msec/echo time msec) for T2-weighted and 600/15 for pre- and postcontrast T1-weighted imaging. Gd-DTPA (Magnevist, 0.2 mmol/Kg; Schering, Germanyl or gadodiamide (Omniscan, $0.2 \mathrm{mmol} / \mathrm{kg}$; Nycomed, Norway) was administered.

CT examinations were performed in four patients (seven lesions) using a Somatom Plus-S (Siemens, Erlangen, Germanyl employing the parameters for brain CT: $120 \mathrm{KVp}, 200 \mathrm{~mA}$, and a slice thickness of 3.0$5.0 \mathrm{~mm}$, with contrast-enhancement after the intravenous administration of nonionic iodinated contrast material (Ultravist, Schering AG, Berlin, Germany). Three lesions of two patients were subject to additional CT scanning of the temporal bone using contiguous 1mm-thick sections with bone windows.

The imaging findings were analyzed for bilaterality, location, and the extent of lesions.

Soft tissue lesions were evaluated for signal intensities on T1- and T2-weighted MR images, attenuation at precontrast CT, and the pattern of contrast enhancement at MRI and CT. The signal intensity of lesions was recorded relative to that of gray matter and was defined as hypointense, isointense, or hyperintense. The attenuation of lesions was compared to that of gray matter on precontrast CT and defined as hypodense, isodense, or hyperdense. Bony destruction was also evaluated in terms of margin and whether there was a periosteal reaction. The margin seen on CT scan was categorized as well- or ill-defined.

\section{Results}

The imaging findings are summarized in Table 1.

Three of the six patients $(50 \%)$ had bilateral temporal bone lesions at the time of presentation. Eight of the nine lesions $(89 \%)$ involved the mastoid, followed by the petrous ridge in six $(67 \%)$, and the squamous portion in three (33\%). Five lesions(56\%) extended to the ipsilateral cavernous sinus $(n=3)$, the sphenoid bone $(n=3)$, or the orbit $(n=2)$. Extension to the epidural space occurred in two $(22 \%)$.

Soft tissue lesions were iso- $(n=5,63 \%)$ (Fig. 1) or hypointense $(n=3,37 \%)$ relative to gray matter on T1weighted images and either hyper- $(n=6,75 \%)$ or isointense $(n=2,25 \%)$ on T2-weighted images. One lesion demonstrated hyperintense foci in its central portion on T1-weighted images, and at pathologic examination, hemorrhagic foci were found to be present there. At precontrast CT, five lesions (71\%) were isodense (Fig. 2) and two (29\%) were hypodense. All lesions were wellenhanced on both MR and CT images. At MR, the enhancement patterns were heterogeneous in six of eight lesions (75\%) and homogeneous in the other two (25\%). Postcontrast CT demonstrated homogeneous enhancement in five of seven lesions (71\%).

CT revealed bony destruction in all lesions with no periosteal reaction. In five lesions $(71 \%)$, ill-defined destruction crossing the suture lines was observed (Fig. 1, $2)$, and in two there was well-defined punched-out destruction in the mastoid portion of the temporal bone.

Table 1. MR and CT Findings of the Temporal Bone LCH

\begin{tabular}{|c|c|c|c|c|c|c|c|c|c|}
\hline Cases & Lesions & Location & Extent & T1WI & $\mathrm{T} 2 \mathrm{WI}$ & Gd-enhan. & Pre-CT & Post-CT & Bone destruction \\
\hline 1 & 1 & Right; mastoid, petrous & Cavernous sinus & Iso. & Iso. & Inhomo & - & 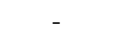 & \\
\hline 2 & 2 & $\begin{array}{l}\text { Left; mastoid, petrous, } \\
\text { squamous }\end{array}$ & $\begin{array}{l}\text { Cavernous sinus } \\
\text { Orbit }\end{array}$ & Hypo. & Hyper. & Inhomo & - & - & - \\
\hline $3^{*}$ & $\begin{array}{l}3 \\
4\end{array}$ & $\begin{array}{l}\text { Left; mastoid, squamous } \\
\text { Righ; mastoid }\end{array}$ & Sphenoid & $\begin{array}{l}\text { Hypo. } \\
\text { Hypo. }\end{array}$ & $\begin{array}{l}\text { Hyper. } \\
\text { Hyper. }\end{array}$ & $\begin{array}{l}\text { Inhomo. } \\
\text { Inhomo. }\end{array}$ & $\begin{array}{l}\text { Hypodense } \\
\text { Isodense }\end{array}$ & $\begin{array}{l}\text { Inhomo. } \\
\text { Homo. }\end{array}$ & $\begin{array}{l}\text { Well-defined } \\
\text { Well-defined }\end{array}$ \\
\hline $4^{*}$ & $\begin{array}{l}5 \\
6\end{array}$ & $\begin{array}{l}\text { Left; mastoid, petrous } \\
\text { Right; mastoid. }\end{array}$ & $\begin{array}{c}\text { Epidural } \\
-\end{array}$ & $\begin{array}{l}\text { Iso. } \\
\text { Iso. }\end{array}$ & $\begin{array}{l}\text { Hyper. } \\
\text { Hyper. }\end{array}$ & $\begin{array}{l}\text { Homo. } \\
\text { Inhomo. }\end{array}$ & $\begin{array}{l}\text { Isodense } \\
\text { Isodense }\end{array}$ & $\begin{array}{l}\text { Homo. } \\
\text { Homo. }\end{array}$ & $\begin{array}{l}\text { Ill-defined } \\
\text { Ill-defined }^{\dagger}\end{array}$ \\
\hline 5 & 7 & $\begin{array}{l}\text { Right; mastoid, squamous } \\
\text { Petrous }\end{array}$ & $\begin{array}{l}\text { Epidural } \\
\text { Sphenoid }\end{array}$ & - & - & - & Isodense & Homo. & Ill-defined $^{\dagger}$ \\
\hline $6^{*}$ & $\begin{array}{l}8 \\
9\end{array}$ & $\begin{array}{l}\text { Left; mastoid, petrous } \\
\text { Right; petrous }\end{array}$ & $\begin{array}{l}\text { Sphenoid } \\
\text { Carvenous sinus }\end{array}$ & $\begin{array}{l}\text { Iso. } \\
\text { Iso. }\end{array}$ & $\begin{array}{l}\text { Hyper. } \\
\text { Iso. }\end{array}$ & $\begin{array}{l}\text { Inhomo. } \\
\text { Homo. }\end{array}$ & $\begin{array}{l}\text { Hypodense } \\
\text { Isodense }\end{array}$ & $\begin{array}{l}\text { Inhomo. } \\
\text { Homo. }\end{array}$ & $\begin{array}{l}\text { Ill-defined } \\
\text { Ill-defined }\end{array}$ \\
\hline
\end{tabular}

Absent; *, Bilateral lesions; +, Temporal bone CT; T1WI, T1-weighted image; T2WI, T2-weighted image; Gd-enhan., Gd-enhancement; Pre-CT, Precontrast CT; Post-CT, Postcontrast CT; Hypo., Hypointense; Iso., Isointense; Hyper., Hyperintense 

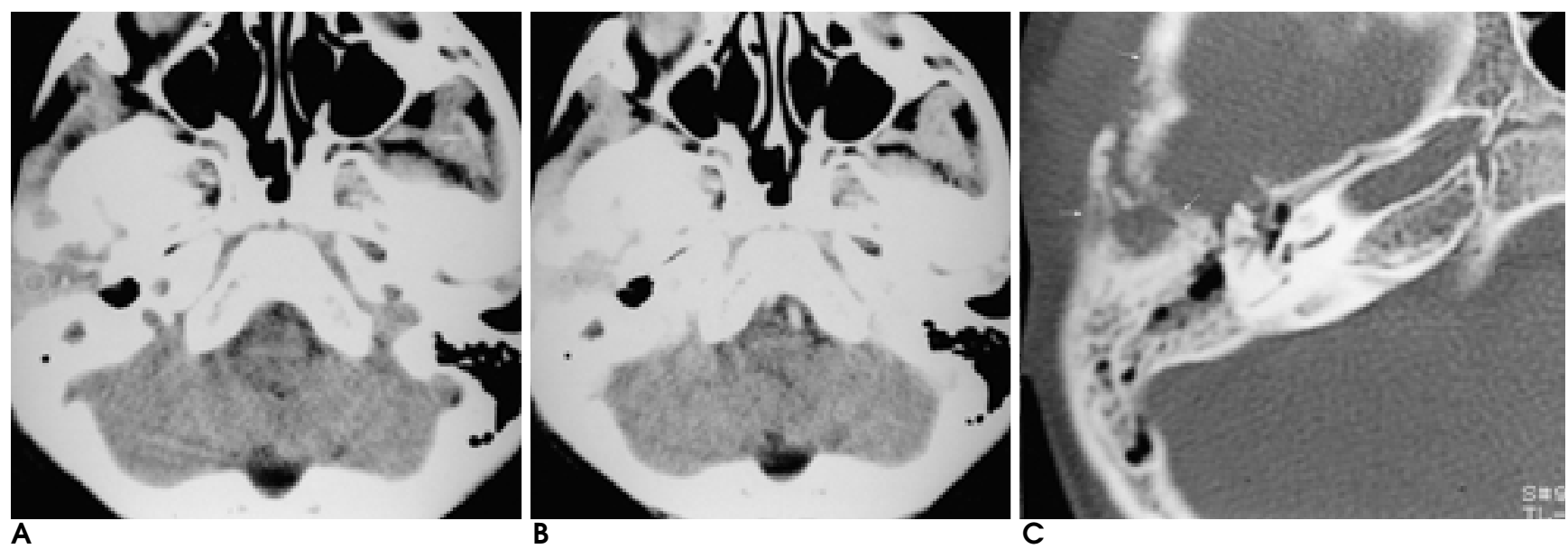

Fig. 2. Lesion 7. A 12-year-old boy presented with a lump in the right auricular region.

Precontrast CT scan (A) shows a relatively isodense soft tissue mass (H.U., 61.4) involving the petrous ridge, mastoid, and the squamous portion of the right temporal bone. Postcontrast axial CT scan (B) reveals a homogeneously enhancing soft tissue lesion (H.U., 80.3). Temporal bone CT scan (C) demonstrates ill-defined bony destruction involving the squamous, petrous, and mastoid portions (arrows) with crossing sutures.

\section{Discussion}

The radiological appearance of $\mathrm{LCH}$ depends on the site of involvement and the phase of the disease (1). In the skull, the calvarium is most frequently involved, followed by the temporal bone, particularly the mastoid and petrous ridges, the sella turcica, and the orbits (6). Reports of imaging findings in $\mathrm{LCH}$ have been confined to cases involving the cranial vault.

The diagnosis of temporal bone $\mathrm{LCH}$ is challenging and can be suggested only as part of a differential diagnosis in the head and neck (5). Aural discharge and swelling over the temporal area are the most frequent presenting symptoms and otitis media and externa are the most frequent clinical findings. Clinically, persistent otitis, refractory to conventional treatment, together with dermatitis of the outer auricular tract, can sugest the presence of $\mathrm{LCH}(2)$.

Bilateral lesions accounted for about $50 \%$ of the cases in our series, and were thus more common than the previously reported frequency of $30 \%$ (2). In our patients, the most frequent site of involvement was the mastoid. Findings of bilateral involvement, extension to the adjacent sphenoid bone or orbit, and epidural extension are consistent with previous reports of LCH of the orbital or another temporal bone (3- 9). These findings mimic aggressive tumors involving the skull base, such as metastatic neuroblastoma, rhabdomyosarcoma, or other malignant tumors.

The signal intensity of LCH has been reported in a limited number of cases (10). Although the signal intensity was not specific in our study, soft tissue lesions were relatively isointense on T1-weighted images. These results are similar to those previously reported $(9$, 10). The lesions in our series were hyper- or isointense on T2-weighted images, and we believe that differences in the signal intensity seen on such images may be attributable to the phase of the disease. Histologically, $\mathrm{LCH}$ is known to be marked by the proliferation of atypical Langerhans cells. During the early phase of $\mathrm{LCH}$, lesions are cellular and marked by aggregates or sheets of Langerhans cells. Older or chronic lesions, however, which may be mistaken for inflammatory lesions, are usually marked by a fibrous background and a paucity of Langerhans cells, with or without eosinophils (1). The pathologic features of the hyperintense lesions seen on T2-weighted images in our series were mainly a fibrous background and occasional histiocytes and eosinophils, suggesting the chronic phase of the disease. Two other isointense lesions seen on T2-weighted images were marked by aggregates of sheets of Langerhans cells. We suggest that isointensity on both T1- and T2-weighted images may reflect the hypercellular nature of $\mathrm{LCH}$ and the active phase of the disease. $\mathrm{LCH}$ should therefore be included in the differential diagnosis of hypercellular tumors, which may be lymphomas, neuroblastomas, rhabdomyosarcomas or chloromas, especially in the pediatric age group. Areas of a lesion which involove hemorrhagic change have also been reported, as in our series (5).

All lesions in our series were well enhanced on both 
MR and CT images, findings which are consistent with those of other studies $(3-5,10)$. In the present series, the enhancement patterns were relatively homogeneous at CT (71\%) but inhomogeneous at MRI (75\%). This discrepancy between CT and MRI may be due to the superior soft tissue resolution and higher contrast of the latter.

The radiologic features of osseous lesions depend on the phase of LCH. During the incipient phase described by Mirra (1), the lesion consists of an osteolytic area with poorly delineated borders and can mimic a malignant tumor, and the lamella shows a periosteal reaction: Ewing' s sarcoma or acute osteomyelitis, and-less frequently-osteosarcoma, leukemia and neuroblastoma metastases are included in the differential diagnosis. The lesion becomes progressively more sharply delineated and a ring of sclerosis may appear, giving it a more benign appearance. CT clearly demonstrates osseous involvement. In most cases in our series, ill-defined permeative destruction involved the mastoid, petrous ridge, and/or the sphenoid bone, with crossing sutures.

These appearances contrast with a previous reports of calvarial or orbital $\mathrm{LCH}$, where the lesions were described as having punched-out defect, with sharp margins $(7-9,12)$.

We suspect that the discrepancies are probably due to delayed manifestation and the advanced stage of the temporal bone lesion. Another factor is that previous studies used conventional CT rather than high-resolution temporal CT with a bone window. We suggest that the latter is an excellent means of determining the nature of an osseous lesion.

Suppurative otitis-mastoiditis may involve the entire mastoid and petrous ridge. An extensive soft tissue mass is not, however, a characteristic of infectious disease. In cholesteatoma an erosive lesion occurs, but often a sharp border and the condition is seldom found in young children, except when congenital in origin. Rhabdomyosarcoma is typically unilateral.
In summary, findings of bilateral involvement, extension to adjacent structures, and signal intensities of soft tissue lesions are not specific for LCH. However, familiarity with findings of predominant mastoid involvement, ill-defined bony destruction with crossing sutures but no periosteal reaction, and a relatively isointense or isodense soft tissue lesion on T1-weighted images or a precontrast CT scan are helpful in narrowing the diagnosis of temporal bone LCH.

\section{References}

1. Mirra JM. Histiocytoses. In: Mirra JM, Picci P, Gold RH, eds. Bone tumors: clinical, radiologic, and pathologic correlations. Philadelphia: Lea \& Febiger, 1989:1021-1060

2. Cunningham MJ, Curtin HD, Jaffe R, Stool SE. Otologic manifestation of Langerhans cell histiocytosis. Arch Otolaryngol Head Neck Surg 1989;115:807-813

3. Hadjigeorgi C, Parpounas C, Zarmakoupis P, Lafoyianni S. Eosinophilic granuloma of the temporal bone: Radiological approach in the pediatric patient. Pediatr Radiol 1990;20:546-549

4. Cunningham MJ, Curtin HD, Butkiewicz BL. Histiocytosis X of the temporal bone: CT findings. J Comput Assist Tomogr 1988;12: 70-74

5. Hermans L, Foer BD, Smet MH, Leysen J, Feenstra L, Fossion E, Baert AL. Eosinophilic granuloma of the head and neck: CT and MRI features in three cases. Pediatr Radiol 1994;24:33-36

6. Stull MA, Kransdorf MJ, Devaney KO. Langerhans cell Histiocytosis of bone. Radiographics 1992;12:801-823

7. Erly WK, Carmody RF, Dryden RM. Orbital histiocytosis X. AJNR Am J Neuroradiol 1995;16:1258-1261

8. Stromberg JS, Wang AM, Huang TE, Vicini FA, Nowak PA. Langerhans Cell Histiocytosis involving the sphenoid sinus and superior orbital fissure. AJNR Am J Neuroradiol 1995;16:964-967

9. Yi G, Yoon HK, Han BK, Kim KA, Choo IW. CT findings of orbital Langerhans cell histiocytosis. J Korean Radiol Soc 2000;42:841-845

10. Monroc M, Pointe DL, Haddad S, Josset P, Montagne JP. Soft tissue signal abnormality associated with eosinophilic granuloma: Correlation of MR imaging with pathologic findings. Pediatr Radiol 1994;24:328-332

11. Rosenfield NS, Abrahams JA, Jomp D. Brain MR in patients with Langerhans cell histiocytosis: Findings and enhancement with GdDTPA. Pediatr Radiol 1990;20:433-436

12. McGahan JP, Osborn RA, Dublin AB, French BN. CT of eosinophilic granuloma of the skull with sonographic correlation. AJNR Am J Neuroradiol 1980;1:576-578 


\title{
측두골 Langerhans세포조직구증의 MR 및 $\mathrm{CT}$ 소견 ${ }^{1}$
}

\author{
${ }^{1}$ 계명의대 동산의료원 진단방사선과학교실 \\ ${ }^{2}$ 계명의대 동산의료원 소아과학교실 \\ 배 재 익. 이 희 정. 김 흥 식
}

목적: 측두골을 침범한 Langerhans세포조직구증의 MR 및 CT 소견을 알아보고자 하였다.

대상과 방법: 6 명의 환아에서 발생한 9 예 병변의 측두골 Langerhans세포조직구증의 MR $(n=8)$ 및 CT $(n=7)$ 소견을 후향적으로 분석하였다. 8예의 병변은 조직학적 소견으로 확진되었고 1예는 임상적으로 진단되었다. 영상소견은 병변 의 양측성, 위치, 침범범위, 연부조직병변의 MR에서의 신호강도와 조영증강전 CT 에서의 음영, 조영증강 양상, CT 소 견에서 골파괴의 양상, 등을 분석하였다.

결과: 양측성 병변은 3 명 $(50 \%)$ 이었다. 병변의 위치는 유양돌기가 8 예( $89 \%)$ 로 가장 많았고 추체부 6 예( $67 \%)$, 인부측 두골 3예( $33 \%)$ 의 순이었다. 7 예( $56 \%$ ) 의 병변이 동측의 해면동 $(n=3)$, 접형골 $(n=3)$, 안와 $(n=2)$, 및 경막외 $(n=2)$ 로 연속적인 침범을 보였다. 연부조직병변은 T 1강조영상에서는 5예(63\%)에서 동등신호강도를, T 2강조영상에서는 6 예 ( $75 \%$ ) 가 고신호강도를 보였다. 조영증강전 CT 에서는 5예( $71 \%$ ) 가 동등음영을 나타내었다. 조영증강은 MR에서는 6 예 $75 \%$ ) 에서 비균일한 양상을, CT 에서는 5예 $(71 \%$ ) 에서 균일한 양상을 보였다. 골파괴는 CT 소견상 전례( $100 \%)$ 에 서 보였으나 골막반응은 관찰되지 않았고, 5 예 $(71 \%)$ 에서 봉합을 건너가는 불규칙한 양상을 보였다.

결론: 병변이 주로 유양돌기( $89 \%)$ 에 위치하고, 연부조직병변이 T 1강조영상에서 동등신호강도 $(63 \%)$ 를 보이고 혹은 조영증간전 CT 에서 동등음영 $71 \%$ ) 이면서 비교적 균일한 조영증강 (51\%) 을 보이며, 봉합을 건너가는 불규칙한 골파 괴(71\%) 소견이 관찰되면 측두엽 Langerhans세포조직구증을 시사하는 것으로 사료된다. 